\title{
Exogenous control of home water preference in the silver shiner
}

\author{
DOMINIC J. COSTANZO and M. DRIVER \\ Muskingum College, New Concord, Ohio 43762
}

Silver shiners were captured and preference tested in a Y-maze, with water taken from their place of capture (home) vs water taken from another part of the stream. Those fish tested with freshly gathered water shortly after capture preferred the arms of the maze containing home water. However, fish held in the laboratory for a long period of time and tested with freshly gathered water failed to show any preference, but the laboratory-held shiners demonstrated a home-water preference when tested with water preserved by freezing which had been gathered at the time of capture.

Hasler (1966) has gathered considerable data supporting the hypothesis that chemicals unique to a given body of water serve as cues enabling migrating salmop to locate their home tributary. Although much attention has been given to the spectacular movements of salmon, there is considerable evidence that many fish display homing behaviors that are dependent upon chemical cues present in water. Field studies of homing in several species which were
Costanzo, in press), but there have been no laboratory discrimination studies between waters taken from the Ss' limited habitats.

Further, Hasler \& Wisby (1951) conditioned bluntnose minnows to water from two separate creeks and found the discrimination to be dependent on the olfactory sense. Since the minnows responded correctly to water gathered at different times of the year as well as to water (preserved by freezing) with which they had initially been trained, it was concluded that the chemicals essential to the discrimination did not change with season. However, observations of natural preferences for home vs novel water in silver shiners and goldfish have shown the home-water preference to change when a long period of time elapsed between capture and testing with freshly gathered water (Taylor \& Costanzo, in press). Retention failure, motivational changes, or changes in the critical water chemistry were possible reasons for the failure to obtain a consistent home water preference over time.

\section{EXPERIMENT 1}

The first experiment was designed to test, with a laboratory preference technique, the ability of the silver shiner, Notropis photogenis, to detect chemical differences occurring within the limited confines of their natural habitat.

Subjects and Apparatus

In late September, approximately 100 silver shiners (48 to $76 \mathrm{~mm}$ in standard length) were captured from two different inlets near the junction of Fox and Crooked Creeks located in Muskingum County, Ohio. It was generally known that these fish aggregate at the mouths of two small inlets to Crooked Creek during the spring and autumn. In late summer and winter, the shiners are absent from these tributaries and are located in the deeper water of Crooked Creek. Half of the shiners were netted from the mouths of each tributary (identified as bridge and field sources), which were only $.15 \mathrm{~km}$ apart. Those fish taken from the bridge source had bridge water defined as the home water and field water defined as the nonhome water, and conversely for fish taken at the other source. This procedure was employed to control for the Ss' responding to some quality other than the home-water aspect of the situation.

The shiners from the two sources were held separately in two well-aerated and filtered 45.5-liter tanks, which were filled with tap water and maintained in the same room containing the test apparatus. An 
Table 1

Mean Time (Skconds) Spent in Y-Maze Arms Containing Home vs Nonhome Water

\begin{tabular}{llccr}
\hline Condition & N & Home & Nonhome & Difference \\
\hline $\begin{array}{c}\text { Experiment 1 } \\
\text { Fresh }\end{array}$ & 15 & 215.5 & 121.7 & $+93.8 * *$ \\
$\begin{array}{l}\text { Experiment 2 } \\
\text { Fresh }\end{array}$ & & & \\
Fresh & 10 & 132.4 & 252.5 & -120.1 \\
\hline
\end{tabular}

$* p<.05, * * p<.02$

independent heating system for the room provided the only temperature control for the aquaria and apparatus $\left(20^{\circ}-25^{\circ} \mathrm{C}\right)$. The animals received a daily ration of commercial fish food, except on test days. The apparatus was a plastic Y-maze described by Taylor \& Costanzo (in press); both arms $(38 \mathrm{~cm})$ provided a slowly flowing stream of tap water, which combined and exited $(760 \mathrm{ml} / \mathrm{min})$ in the startbox via an overflow pipe. The overflow pipe maintained a constant $6.2-\mathrm{cm}$ water depth during trials, but allowed rapid flushing of the maze between trials. Water from the home and nonhome sources dripped from two 1-liter bottles into the maze arms. Each bottle's flow was regulated through Abbott Laboratories' Venopak tubing and valves at the rate of approximately $4 \mathrm{ml} / \mathrm{min}$.

Procedure and Results

After the shiners were housed 10 days in the laboratory aquaria, fresh water was gathered from the bridge and field sources, the presence of other shiners in the inlets noted, and 20 of the animals were individually tested. Each S was netted and confined by a gate in the startbox, with the home and nonhome streams flowing. After $5 \mathrm{~min}$ of acclimation time, the gate was raised and for 15 min the time spent in each of the stream arms was recorded. At the end of a trial, $S$ was removed and the maze was drained, filled, and drained again. The order of testing Ss from the field and bridge sources was alternated, and the position of the home and nonhome arms of the $\mathrm{Y}$-maze was counterbalanced. Each $\mathrm{S}$ was tested only once. If a $S$ stayed in the startbox or darted out and remained immobile for the entire trial, it was dropped from the study. Of the $20 \mathrm{Ss}$ tested, 5 were discarded.

Table 1 shows the mean time Ss spent investigating the maze arms containing home vs nonhome water. The mean difference score (home minus nonhome) reflects that the shiners spent significantly more time in the home arm of the maze (Wilcoxon matched-pairs, signed-ranks test, $\mathrm{T}=19, \mathrm{p}<.02$ ).

\section{EXPERIMENT 2}

Since trained bluntnose minnows responded equally well to water gathered in winter and the preserved water to which they were originally trained (Hasler \& Wisby, 1951), the second experiment was performed to determine if the preference for home water in the silver shiner was also independent of changes in the chemical characteristics of the water Procedure and Results

The same procedure and remaining Ss were employed, only testing was done $\mathbf{2 7 0}$ days after their capture. The field and bridge Ss were assigned randomly to one of two groups. One group was tested with freshly gathered source water, while the other group's preferences were observed using water (preserved by freezing) that was obtained when the first experiment was performed. There were no shiners in the designated home areas of the streams at this time.

Table 1 shows the time spent investigating home and nonhome maze arms under both experimental conditions. Those shiners tested with water gathered and frozen in September, preferred the home water arm of the maze $(T=6, p<.05)$. Although those Ss presented with freshly gathered water spent more time investigating the nonhome maze arm, the mean difference of $-120.1 \mathrm{sec}$ did not represent a significant preference $(T=18.5)$. Since the. sample size was rather small and $80 \%$ of these Ss spent more time in the nonhome stream, there is a good possibility that a larger sample would have demonstrated a preference for the nonhome water.

The observed differences in total investigation time (home plus nonhome) were not significant (Kruskal-Wallis test, $\mathrm{H}=3.95$ ), indicating that the length of maintenance and the use of fresh or preserved source water had no effect on the tendency of the Ss to investigate the maze choice arms.

$$
\text { DISCUSSION }
$$

The ability of silver shiners to detect chemical differences found in their natural habitat was readily demonstrated, using a preference technique. Evidently, those chemical aspets of water which are utilized in home-area recognition change and the instability of the S's preference for home water was related to these changes. Retention difficulties cannot account for the failure of the shiners tested with fresh source water to maintain the home-water preference when tested 270 days after capture, since those animals tested with the preserved source water demonstrated the home-water preference.

The data support the results of an earlier study which demonstrated an unstable preference for home water in the silver shiner (Taylor \& Costanzo, in press). The results do not seem to agree with the conclusion of Hasler \& Wisby (1951), that a constant chemical quality in a stream is relied upon for recognition of particular tributaries. In the present study, it is evident that a chemical change took place. However, it is possible that some other aspect of the stream's chemistry, besides its home-area quality, had changed. The presence or absence of this unknown factor may have served to induce the shiners to seek out the home area which could always be detected. The presence of milt and sperm from the green sunfish has been shown to attract and induce spawning in the redfin shiner (Hunter \& Hasler, 1965) . Even food substances which were present seasonally could have served to induce the silver shiners to orient to a particular area in their environment. This interpretation gives us some difficulty, since, if the Ss were generally attracted by the presence of food or other animals, some differences in the overall investigation times between groups should have been evident, yet no significant differences were observed. Although it is not clear if the home quality or some unknown factor was varied, a chemical change in the environment was responsible for the failure to obtain a home-water preference with water gathered during thy winter.

Several environmental factors (temperature, photoperiod, stream level, etc.) have been shown to regulate the movements of fish populations (Northcote, 1967). The data suggests that varying chemical factors are also of importance.

\section{REFERENCES}

HASLER, A. D. Underwater guideposts. Madison: University of Wisconsin Press. 1966.

HASLER, A. D. \& WISBY, W. J. Discrimination of stream odors by fishes and relation to parent stream behavior. American Naturalist, $1951,85,223-238$.

HUNTER, J. R., \& HASLER, A. D Spawning association of the redfin shiner, Notropis umbratilis, and the green sunfish, Lepomis cyanellus. Copeia, 1965. 3. 265-281.

NORTHCOTE, T. G. The relation of movements and migrations to production in freshwater fishes. In S. D. Gerking (Ed.). The biolosical basis of freshwater fish production. Oxford: Blackwell, 1967. Pp. 315-344.

TAYLOR, L. R., \& COSTANZO, D. J. Preferences of fish for home waters. Journal of Genetic Psvchologv, in press. 